Article

\title{
Thymus vulgaris Essential Oil Protects Zebrafish against Cognitive Dysfunction by Regulating Cholinergic and Antioxidants Systems
}

\author{
Luminita Capatina ${ }^{1,+} \oplus$, Elena Todirascu-Ciornea ${ }^{1,+}$, Edoardo Marco Napoli ${ }^{2}{ }^{(D}$, \\ Giuseppe Ruberto $^{2}$, Lucian Hritcu ${ }^{1, *(\mathbb{D})}$ and Gabriela Dumitru ${ }^{1}$ \\ 1 Department of Biology, Faculty of Biology, Alexandru Ioan Cuza University of Iasi, 700506 Iasi, Romania; \\ luminita.capatina@student.uaic.ro (L.C.); ciornea@uaic.ro (E.T.-C.); gabriela.dumitru@uaic.ro (G.D.) \\ 2 Institute of Biomolecular Chemistry, National Research Council ICB-CNR, 95126 Catania, Italy; \\ edoardo.napoli@icb.cnr.it (E.M.N.); giuseppe.ruberto@icb.cnr.it (G.R.) \\ * Correspondence: hritcu@uaic.ro; Tel.: +40-232-201-666 \\ + These authors contributed equally to this work.
}

Received: 22 September 2020; Accepted: 2 November 2020; Published: 4 November 2020

\begin{abstract}
Thymus vulgaris L. is an aromatic herb used for medicinal purposes such as antimicrobial, spasmolytic, antioxidant, anti-inflammatory, antinociceptive, antitumor, and may have beneficial effects in the treatment of Alzheimer's disease. The present study aimed to investigate whether Thymus vulgaris L. essential oil enhances cognitive function via the action on cholinergic neurons using scopolamine (Sco)-induced zebrafish (Danio rerio) model of memory impairments. Thymus vulgaris $\mathrm{L}$. essential oil (TEO, 25, 150, and $300 \mu \mathrm{L} / \mathrm{L}$ ) was administered by immersion to zebrafish once daily for 13 days, whereas memory impairment was induced by Sco $(100 \mu \mathrm{M})$, a muscarinic receptor antagonist, delivered $30 \mathrm{~min}$ before behavioral tests. Spatial memory was assessed using the Y-maze test and novel object recognition test (NOR). Anxiety and depression were measured in the novel tank diving test (NTT). Gas Chromatograph-Mass Spectrometry (GC-MS) analysis was used to study the phytochemical composition of TEO. Acetylcholinesterase (AChE) activity and oxidative stress response in the brain of zebrafish were determined. TEO ameliorated Sco-induced increasing of AChE activity, amnesia, anxiety, and reduced the brain antioxidant capacity. These results suggest that TEO may have preventive and/or therapeutic potentials in the management of memory deficits and brain oxidative stress in zebrafish with amnesia.
\end{abstract}

Keywords: Thymus vulgaris; essential oil; scopolamine; anxiety; memory; oxidative stress

\section{Introduction}

Alzheimer's disease (AD) is a progressive neurodegenerative condition with significant variability in clinical characteristics and biomarkers and numerous genetic and environmental factors implicated in its etiology and development $[1,2]$. Moreover, $\mathrm{AD}$ is the most prevalent type of dementia in the world and is medically characterized as the pathological deposition of folded $\beta$-amyloid $(A \beta)$ plaques and hyperphosphorylated neurofibrillary tau tangles in the brain leading to neurodegeneration $[3,4]$. Clinically, AD poses issues of progressive episodic memory and executive performance across cognitive continuums ranging from cognitively unimpaired (CU), moderate cognitive impairment (MCI), to AD [3]. Numerous studies on the brains of AD and dementia patients have consistently reported defects or damage to central cholinergic pathways [5]. Given this, the treatment of AD-related dementia is typically done through the use of acetylcholinesterase (AChE) inhibitors, such as donepezil [6]. Non-cognitive symptoms associated with $\mathrm{AD}$ and related dementias include insanity (delusions, 
hallucinations), mood disorders (depression, euphoria, irritability, anxiety), behavioral changes (disinhibition, apathy), agitation, anger, slowness, wandering, altered sexual activity, modified sleep habits, and eating disorders [7]. Oxidative stress is known to be a very significant factor in ageing and age-related disorders and a large amount of research has shown that oxidative stress is an important pathogenic factor in AD [8]. Protein oxidation markers, such as protein carbonyls, have been shown to be increased in AD brains in areas with proven histopathological AD characteristics [9]. Protein carbonyls and 3-nitrotyrosine (3-NT) levels have been increased in the frontal cortex of individuals with MCI, mild $\mathrm{AD}$, and $\mathrm{AD}$, with no distinction between disease stages, a finding that supports the concept of oxidative stress as an early event in AD [10].

Scopolamine (Sco) is a cholinergic antagonist of the muscarinic acetylcholine receptors known to interfere with acetylcholine production in the central nervous system. This drug was used as a guide for the induction of amnesia in animal models [11-14]. The most important characteristic of dementia is memory deterioration, which may be chemically caused by the use of Sco in laboratory animals. The effect of Sco on memory is followed by central cholinergic dysfunction and oxidative stress in zebrafish [15]. Sco has been characterized as an amnestic agent in zebrafish and is widely used to study memory formation and rescue in conjunction with nootropic and memory-enhancing drugs [12]. Additionally, Sco has been reported to induce cholinergic deficits and memory impairment via the up-regulation of AChE activity [16]. Furthermore, there is increasing evidence that Sco interferes with the molecular homeostasis of the extracellular signal-regulated kinase (ERK) and cAMP response element-binding (CREB)/brain-derived neurotrophic factor (BDNF) in animal models $[17,18]$ while simulating ERK/CREB/BDNF injury in the brains of patients with $\mathrm{AD}[19,20]$.

There is no treatment for AD. However, there are medications available that can alleviate symptoms temporarily. Currently, only a few medications are available on the market with multiple adverse effects. Donepezil is the second approved AChE inhibitor for the treatment of mild to moderate AD by the United States Food and Drug Administration (FDA), extensively used worldwide [21]. As donepezil is generally tolerated, most adverse events are nausea, vomiting, diarrhea, muscle cramps, fatigue, and weight loss [22]. Additionally, rivastigmine commonly used as an AChE inhibitor could induce side effects such as nausea, vomiting, diarrhea, weight loss, indigestion, and muscle weakness [23]. Besides, memantine used for treating dementia exhibited different side effects such as dizziness, headache, diarrhea, constipation, and confusion [24]. Natural products from plants represent interesting candidates for the treatment of $\mathrm{AD}$ and the present study aimed to identify if the Thymus vulgaris essential oil (TEO) is a potent source of bioactive compounds to counteract AD [25].

The genus Thymus (Lamiaceae family) comprises over 300 species of aromatic perennial herbaceous plants with important medicinal properties [26]. Thyme oil has been widely used in the food, pharmaceutical, and cosmetic industries due to its various biological processes. Biological properties include antioxidant, anti-inflammatory, anti-tumor, and anti-microbial effects [27].

The chemical composition of the TEO has been documented. Thymol has generally been identified to be the main constituent of Thymus vulgaris, accompanied by carvacrol and linalool [28]. These compounds have been stated to have also therapeutic properties (e.g., vs. AD) [29]. For instance, Asadbegi et al. [30] demonstrated that thymol decreased the effect on memory damage caused by intrahippocampal injection of the $A \beta$ peptide in high-fat diet-fed rats and could be found as neuroprotective. Additionally, Capibaride et al. [31], confirmed the marked antidepressant-like effect of thymol, as demonstrated by its ability to reverse chronic corticosterone-associated behavior and a decrease in BDNF levels in female mice. Furthermore, Formiga et al. [32] suggested the intestinal anti-inflammatory function of $p$-cymene and rosmarinic acid involving the cytoprotection of the intestinal barrier, the preservation of the mucus layer, and the conservation of communicating junctions, as well as the regulation of the antioxidant and immunomodulatory processes. Azizi et al. [33] demonstrated that the neuroprotective effects of carvacrol and thymol against A $\beta 25-35$ might be through attenuating oxidative damage and increasing the activity of PKC as a memory-related protein. Besides, $\beta$-myrcene and caryophyllene within the monoterpenes and sesquiterpenes have been identified as 
the major compounds. $\beta$-myrcene is known to have analgesic, anxiolytic, and anti-inflammatory effects [34,35]. Caryophyllene was known as an anti-inflammatory compound in some Cannabis extracts due to interactions with cannabinoid receptors and gastric cytoprotective activity [36]. Notably, caryophyllene oxide appears to be a multi-target molecule known for its anti-cancer and analgesic properties [35].

In zebrafish, the essential oils from Thymus quinquecostatus Celak. from the Loess Plateau in China exhibited antioxidant potential mainly by regulating the Nrf2/Keap1 signaling pathway. Rabiei et al. [37] reported that Thymus vulgaris extract has remedial on memory and behavioral disturbances caused by Sco and may have beneficial effects in the treatment of AD. Elaissi et al. [38] demonstrated antiproliferative activities of Thymus numidicus Poir. against two human cancer cell lines: the colonic (HCT116) and breast adenocarcinoma (MCF7), respectively. Butt et al. [39] demonstrated that the TEO was found to be a good source of thymoquinone as a chemotherapeutic drug that expressed potent antioxidant and antiproliferative activities. To date, no study indicated the TEO positive effects on memory function in zebrafish against Sco-induced cognitive dysfunction by regulating cholinergic and antioxidant pathways. The present study was therefore organized to examine the phytochemical composition of the TEO and to evaluate the effects on anxiety, cognitive performance, and the brain antioxidant capability in a zebrafish Sco model of amnesia.

\section{Materials and Methods}

\subsection{Essential Oil and Chemical Material}

The TEO used in this study is a commercial sample produced with organic plant material and kindly supplied by Flora S.R.L. (Lorenzana, Pisa, Italy), batch no. 162371. The standard mix of $n$-alkanes $C_{9}-C_{22}$ was purchased by Alltech (Bologna, Italy).

\subsection{Gas Chromatograph-Mass Spectrometry (GC-MS) Analysis}

To obtain the chromatographic profile of the essential oil a Shimadzu GC-17A Gas Chromatograph (Shimadzu, Milan, Italy) equipped with a $15 \mathrm{~m} \times 0.1 \mathrm{~mm} \times 0.1 \mathrm{~mm}$ fused silica capillary column (Supelco SPB ${ }^{\mathrm{TM}}-5$, Merk KGaA, Darmstadt, Germany) and Flame Ionization Detector (FID) was used. GC-MS analyses were performed on a Shimadzu GCMS-QP5050A (Shimadzu, Milan, Italy). The operating conditions for both runs were the following: $60^{\circ} \mathrm{C}$ for $1 \mathrm{~min}, 60-280^{\circ} \mathrm{C}$ at $10^{\circ} \mathrm{C} / \mathrm{min}$ then $280^{\circ} \mathrm{C}$ for $1 \mathrm{~min}$; injector temperature $250^{\circ} \mathrm{C}$; detector temperature $280^{\circ} \mathrm{C}$; carrier gas helium $(1 \mathrm{~mL} / \mathrm{min})$; split mode (1:200), the volume of injection $1 \mathrm{~mL}\left(4 \%\right.$ essential oil/ $\mathrm{CH}_{2} \mathrm{Cl}_{2} v / v$ ). Percentages of compounds were determined from their peak areas in the GC-FID profiles. Mass spectrometer parameters were the following: Ionization at $70 \mathrm{eV}$, ion source temperature $180^{\circ} \mathrm{C}$. Mass spectral data were acquired in the scan mode in $\mathrm{m} / \mathrm{z}$ range $40-400$. Oil solutions were injected with the split mode (1:96) [40].

The identity of components was based on their retention index relative to $C_{9}-C_{22} n$-alkanes on the $\mathrm{SPB}^{\mathrm{TM}}-5$ column and computer matching of spectral MS data with those from NIST MS 107 and NIST 21 libraries [41], the comparison of the fragmentation patterns with those reported in the literature [42].

\subsection{Animals}

50 adults zebrafish (Danio rerio) wild-type short-fin strain of both sexes (ratio: 50:50 male: Female, 3-4 month-old, and 3-4 cm-long) were purchased from a specialized commercial supplier (Pet Product S.R.L., Bucharest, Romania). The zebrafish were acclimatized in the experimental room for at least 14 days. Fish were sorted in groups of 10 fish in $24 \mathrm{~L}$ thermostated $\left(26 \pm 1{ }^{\circ} \mathrm{C}\right)$ tanks, kept under water filtration and aeration (7.2 $\left.\mathrm{mg} \mathrm{O}_{2} / \mathrm{L}\right)$ using Tetratec ${ }^{\circledR}$ air pumps (Tetra, Melle, Germany). Animals were maintained on 14/10 h light/dark cycle, and were fed twice a day with Norwin Norvitall flake (Norwin, Gadstrup, Denmark). In behavioral studies, acclimatized zebrafish were randomly assigned to the control, the Sco $(100 \mu \mathrm{M})$, and three TEO treatment groups $(25,150$, and $300 \mu \mathrm{L} / \mathrm{L})$. The essential oil $[43,44]$ and the Sco [45] doses were selected according to previous studies. TEO $(25,150$, 
and $300 \mu \mathrm{L} / \mathrm{L}$ ) was diluted with $1 \%$ Tween-80 solution and was administered to zebrafish by immersion for $1 \mathrm{~h}$, once daily for 13 days, while Sco $(100 \mu \mathrm{M})$ was administered $30 \mathrm{~min}$ before each behavioral tests. The control group was immersed only in unchlorinated water with a $1 \%$ Tween-80 solution. All experiments (as outlined in Figure 1) were carried out following scrutiny by the Ethics Committee on Animal Research of the Alexandru Ioan Cuza University of Iasi, Faculty of Biology (Iasi, Romania) under license no. 02/30.06.2020 and fully complied with the Directive 2010/63/EU of the European Parliament and of the Council of 22 September 2010 on the safety of animals. The health status and the well-being of all animals involved in the research have been tested regularly during the behavioral tests. No procedures have caused serious pain or long-lasting damage to the zebrafish, and no experimental subject has died during the experimental procedures (fish housing and behavioral tests).

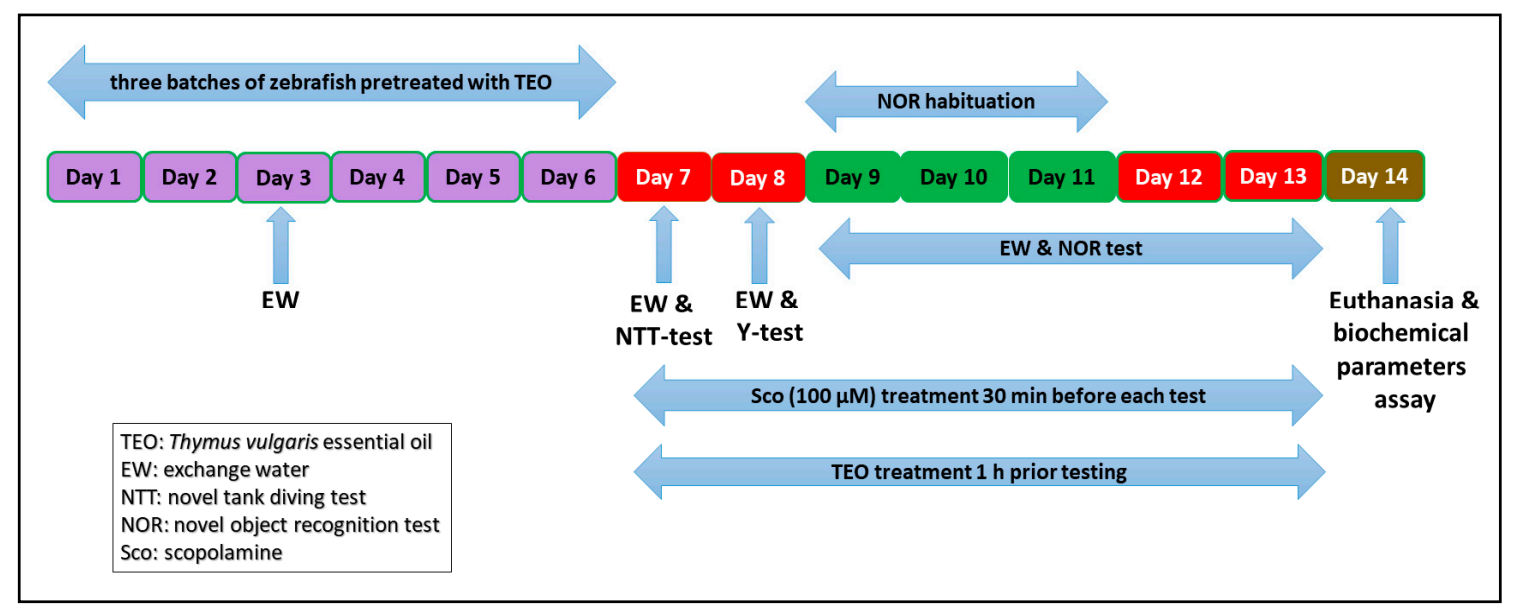

Figure 1. Experimental design procedure for the Thymus vulgaris essential oil administration, behavioral study, and biochemical analysis.

\subsection{Behavioral Assay}

\subsubsection{Novel Tank Diving Test (NTT)}

The NTT is a particular test used to evaluate anxiety in zebrafish, as defined by Cachat et al. [46]. The trapezoidal tank $(1.5 \mathrm{~L})$ used measured 15.2 height $\times 27.9$ top $\times 22.5$ bottom $\times 7.1$ width $\mathrm{cm}$, equally divided into two horizontal sections (top and bottom). Following $1 \mathrm{~h}$ of TEO treatment, the animals were placed individually within the test tank without acclimatization, and swimming behavior was recorded for $6 \mathrm{~min}$. The animals were recorded with a Logitech HD Webcam C922 Pro Stream camera (Logitech, Lausanne, Switzerland) placed $30 \mathrm{~cm}$ away from the tank and the videos were analyzed using ANY-Maze ${ }^{\circledR}$ software (Stoelting CO, Wood Dale, IL, USA). Representative tracking images of the zebrafish locomotor activity for each group was obtained at the end of the analysis with ANY-Maze ${ }^{\circledR}$ software. The following parameters heve been recorded: The time spent in the top/bottom zone of the tank (s), total distance traveled $(\mathrm{m})$, and average velocity $(\mathrm{m} / \mathrm{s})$.

\subsubsection{Y-Maze Test}

Spatial memory and the response to novelty in zebrafish was assessed using the Y-maze task [47]. The location in the Y-maze task was considered to be a memory index [45]. The apparatus consisted in a Y-maze glass tank with three identical arms (25 cm long, $8 \mathrm{~cm}$ wide, and $15 \mathrm{~cm}$ high), filled with $3 \mathrm{~L}$ of the the home aquarium water. The water high in the Y-maze was $13 \mathrm{~cm}$. Explicit geometric shapes (squares, circles, and triangles) were placed on the outer walls and visible from the inside. The Y-maze test consisted in two trials separated by $1 \mathrm{~h}$ interval. During the first trial, $1 \mathrm{~h}$ after TEO treatment, the fish could freely swim in the start arm and in the other arm for 5 min while the novel arm was blocked by a dividing wall. In the second trial, the wall was removed and the fish could explore for 
$5 \mathrm{~min}$ all three arms including the novel environment constituted by the novel arm. Fish were placed in different arms as starting points and the maze was rotated in each experiment to randomize the maze cues. The water was changed between groups and trials. The behavior was fully analyzed using the ANY-Maze ${ }^{\circledR}$ software (Stoelting CO, Wood Dale, IL, USA), assessing time spent in each arm (percent of the total time), total distance traveled $(\mathrm{m})$, turn angle $\left({ }^{\circ}\right)$, and the preference percentages. The preference percentages were calculated as (time of exploration of the novel arm/time of exploration of the start + time of exploration of the other arm + time of exploration of the novel arm $\times 100$ ).

\subsubsection{Novel Object Recognition Test (NOR)}

NOR is a widely used behavioral assay in zebrafish to examine the memory efficiency [48]. The experimental apparatus consists of a 20 L glass tank $(30 \times 30 \times 30 \mathrm{~cm})$ filled with $6 \mathrm{~cm}$ of water. The NOR test consists of three phases. In the habituation phase, each animal explores the tank in the absence of the objects for $5 \mathrm{~min}$ twice a day ( $5 \mathrm{~h}$ interval between habituation sessions) over 3 consecutive days. In the training phase (on the 4th day), the animals were exposed to two identical hard plastic red cubes for $10 \mathrm{~min}$. In the test phase ( $1 \mathrm{~h}$ after the training phase), a novel object ( $\mathrm{N}$, green cube) replaced one of the copies of the familiar objects ( $\mathrm{F}$, red cubes), and the exploration time of each object was evaluated for $10 \mathrm{~min}$. The exploration area was established by increasing once the size of the object area; thus, we considered exploration when the fish were up to $2.5 \mathrm{~cm}$ far from each side of the object. The behavior was fully analyzed using the ANY-Maze ${ }^{\circledR}$ software (Stoelting CO, Wood Dale, IL, USA), assessing the exploratory time (s) and the preference percentages. The preference percentages have been determined as (time of exploration of N/time of exploration of $\mathrm{F}+$ time of exploration of $\mathrm{N} \times 100)$ [15].

\subsection{Biochemical Parameters Assay}

Immediately after behavioral tests, all zebrafish were euthanized (10 min immersion in ice-water, $2-4{ }^{\circ} \mathrm{C}$ ) until loss of opercular motions [49], and then, the brains were isolated for the analysis of the biochemical parameters. In ice $0.1 \mathrm{M}$ potassium phosphate buffer $(\mathrm{pH} 7.4), 1.15 \% \mathrm{KCl}$ with Potter Homogenizer, the brains were gently homogenized. The resulted homogenate was centrifuged at $960 \times \mathrm{g}$ for $15 \mathrm{~min}$. The supernatant was used for the estimation of acetylcholinesterase (AChE), superoxide dismutase (SOD), and glutathione peroxidase (GPX) specific activities, the total content of reduced glutathione (GSH), protein carbonyl, and malondialdehyde (MDA) level.

\subsubsection{AChE Activity}

The activity of acetylcholinesterase (AChE, EC 3.1.1.7) was determined by the defined approach as previously described by Ellman et al. [50], using acetylthiocholine chloride (ATC) as artificial substrate. The reaction mixture $(600 \mu \mathrm{L})$ included $0.26 \mathrm{M}$ phosphate buffer with $\mathrm{pH} 7.4,1 \mathrm{mM} 5.5^{\prime}$-dithiobis-2 nitrobenzoic acid (DTNB), and $5 \mathrm{mM}$ ATC. The assay was started by adding supernatant and then by developing the yellow color at $412 \mathrm{~nm}$ for $10 \mathrm{~min}$ at room temperature. Suitable controls have been performed for the non-enzymatic hydrolysis of ATC. The specific activity of the enzyme was formulated as nmol of $\mathrm{ACT} / \mathrm{min}$ per/mg of protein.

\subsubsection{SOD Activity}

The activity of superoxide dismutase (SOD, EC 1.15.1.1) was determined as described by Winterbourn et al. [51]. The reaction mixture $(1.5 \mathrm{~mL})$ contained $100 \mathrm{mM}$ TRIS/ $\mathrm{HCl}(\mathrm{pH} 7.8)$, $75 \mathrm{mM}$ NBT, $2 \mu \mathrm{M}$ riboflavin, $6 \mathrm{mM}$ EDTA, and $200 \mu \mathrm{L}$ supernatant. The monitoring of the increase in absorbance at $560 \mathrm{~nm}$ followed the blue formazan output. One unit of SOD is defined as the amount of the enzyme required to inhibit the rate of NBT reduction by 50\%. The specific activity of the enzyme was expressed in units/mg protein. 


\subsubsection{GPX Activity}

Glutathione peroxidase (GPX, E.C. 1.11.1.9) activity was analyzed as described by Sharma and Gupta [52]. A reaction mixture consisting of $1 \mathrm{~mL} 0.4 \mathrm{mM}$ phosphate buffer ( $\mathrm{pH} 7.0$ ) containing $0.4 \mathrm{mM}$ EDTA, $1 \mathrm{~mL}$ of $5 \mathrm{mM} \mathrm{NaN}_{3}, 1 \mathrm{~mL}$ of $4 \mathrm{mM}$ glutathione (GSH), and $200 \mu \mathrm{L}$ of supernatant was pre-incubated at $37^{\circ} \mathrm{C}$ for $5 \mathrm{~min}$. Then $1 \mathrm{~mL}$ of $4 \mathrm{mM} \mathrm{H}_{2} \mathrm{O}_{2}$ was inserted and incubated at $37^{\circ} \mathrm{C}$ for a further $5 \mathrm{~min}$. The GSH excess was quantified by the 5,5'-dithiobis-2-nitrobenzoic acid (DTNB) method. One unit of GPX is defined as the amount of enzyme required to oxidize for $1 \mathrm{nmol} \mathrm{GSH} / \mathrm{min}$. The enzyme specific activity was expressed as units/mg protein.

\subsubsection{GSH Content}

The reduced glutathione (GSH) content was assessed in the zebrafish brain supernatant using the method of Fukuzawa and Tokumura [53]. $200 \mu \mathrm{L}$ of brain supernatant was mixed with $1.1 \mathrm{~mL}$ of $0.25 \mathrm{M}$ sodium phosphate buffer $(\mathrm{pH}=7.4$ ) followed by the addition of $130 \mu \mathrm{L}$ DTNB $0.04 \%$. Finally, the mixture was fixed to a final volume of $1.5 \mathrm{~mL}$ with distilled water, and absorbance was read at $412 \mathrm{~nm}$ using a spectrophotometer. The results were presented as $\mu \mathrm{g} \mathrm{GSH} / \mu \mathrm{g}$ protein.

\subsubsection{Protein Carbonyl Level}

By measuring the content of protein carbonyl groups, the degree of protein oxidation in the brain was evaluated using a method defined by Oliver et al. [54], and updated by Luo and Wehr [55]. The supernatant fraction was divided into two equal aliquots, each containing around $2 \mathrm{mg}$ of protein. Using $10 \%$ trichloroacetic acid (TCA, $w / v$, final concentration), both aliquots were precipitated. Another sample was treated with $2 \mathrm{~N} \mathrm{HCl}$, and another sample was treated with an equal volume of $0.2 \%(w / v) \mathrm{DNPH}$ in $2 \mathrm{~N} \mathrm{HCl}$. At $25^{\circ} \mathrm{C}$, both samples were incubated and then stirred at intervals of $5 \mathrm{~min}$. The results were expressed as $\mathrm{nmol} / \mathrm{mg}$ protein.

\subsubsection{MDA Level}

A malondialdehyde (MDA) level assay was performed according to previous protocol described by Ohkawa et al. [56]. For this assay, $200 \mu \mathrm{L}$ of supernatant was mixed with $0.1 \mathrm{M} \mathrm{HCl}$ with $1 \mathrm{~mL}$ of $50 \%$ TCA in $0.1 \mathrm{M} \mathrm{HCl}$ and $1 \mathrm{~mL}$ of $26 \mathrm{mM}$ thiobarbituric acid. After vortex mixing, samples were held at $95{ }^{\circ} \mathrm{C}$ for $20 \mathrm{~min}$. The samples were then centrifuged at $960 \times \mathrm{g}$ for $10 \mathrm{~min}$, and the supernatants were read at $532 \mathrm{~nm}$ against the control. The concentration of MDA was presented as nmol/mg protein.

\subsubsection{Protein Concentration}

The protein content was estimated through Bradford's dye-binding assay. $0.8 \mathrm{~mL}$ of Roti ${ }^{\circledR}$ Quant reagent (Carl Roth, Germany) was mixed with up to $200 \mu \mathrm{L}$ of the sample, and the change in absorbance at $595 \mathrm{~nm}$ was measured using a DU ${ }^{\circledR} 740$ Life Science spectrophotometer (Beckman Coulter, Brea, CA, USA). A calibration curve in the range of 2 to $20 \mu \mathrm{g}$ was constructed using bovine serum albumin (BSA). Protein concentration was expressed as $\mu \mathrm{g} B S A / \mu \mathrm{L}$ of clear homogenate [57].

\subsection{Statistical Analysis}

All results are expressed as mean \pm standard error of the mean (S.E.M) and were analyzed by GraphPad Prism 8.0 software (GraphPad Software, Inc., San Diego, CA, USA). The normality of data distribution was evaluated using Shapiro-Wilk-Test. Datasets with multiple comparisons were evaluated using one-way ANOVA followed by Tukey's post hoc test. $p<0.05$ was considered to indicate a statistically significant difference. In the preference experiments within the Y-maze and NOR tests, one sample $t$-test was used for comparison of the preference to chance level $(50 \%)$. The Pearson correlation coefficient ( $r$ ) was used to estimate the correlation between the behavioral scores, enzymatic activities, and lipid peroxidation. 


\section{Results and Discussion}

\subsection{The Chemical Composition of the Thymus vulgaris Essential Oil}

From a chemical point of view, TEO is generally characterized by a large amount of monoterpenes (both hydrocarbons and oxygenated) reaching almost $90 \%$ of the whole oil. The two main phenolic monoterpenes, thymol, and carvacrol occur more frequently. These are always accompanied by $p$-cymene and $\gamma$-terpinene being strictly biogenetically correlated with thymol and carvacrol $[58,59]$. Thymus is probably the most taxonomically complex genus of the Lamiaceae family. Several studies confirming the presence of a significant intraspecific chemical diversity in which the two most common chemotypes, thymol, and carvacrol, are preponderant [60], followed by less common non-phenolic chemotypes [61]. In particular, the sample subject of this study has a chemical profile quite typical of Thymus vulgaris, thymol chemotype. Gas chromatography analysis allowed the identification of more than 70 components covering more than $98 \%$ of the total oil composition. Table 1 shows the detail of the chemical composition, listing only the 41 components with the percentage $>0.05$. The most represented class is that of oxygenated monoterpenes (59.95\%), followed by hydrocarbon monoterpenes (29.45\%), the sum of which reaches $89 \%$. Sesquiterpenes and other components are below 10\%. The main compound is thymol (42.10\%), followed by $p$-cymene $(19.20 \%)$ and the sesquiterpene $\beta$-caryophyllene $(6.40 \%)$. Carvacrol is below $3 \%$.

Table 1. Chemical composition of commercial Thymus vulgaris essential oil.

\begin{tabular}{|c|c|c|c|c|}
\hline$\#^{\mathbf{a}}$ & RI Lit ${ }^{b}$ & RI $\operatorname{Exp}^{c}$ & Class/Compound ${ }^{d}$ & $\%$ e \\
\hline & & & Monoterpene hydrocarbons & 29.45 \\
\hline 2 & 927 & 923 & Tricyclene & 0.07 \\
\hline 3 & 930 & 927 & $\alpha$-Thujene & 0.30 \\
\hline 4 & 939 & 934 & $\alpha$-Pinene & 1.52 \\
\hline 5 & 954 & 949 & Camphene & 1.73 \\
\hline 7 & 991 & 988 & $\beta$-Myrcene & 1.63 \\
\hline 8 & 1003 & 1001 & $\alpha$-Phellandrene & 0.12 \\
\hline 9 & 1017 & 1015 & $\alpha$-Terpinene & 0.89 \\
\hline 10 & 1025 & 1025 & $p$-Cymene & 19.20 \\
\hline 11 & 1029 & 1028 & Limonene & 0.48 \\
\hline 13 & 1060 & 1058 & $\gamma$-Terpinene & 3.43 \\
\hline \multirow[t]{2}{*}{16} & 1089 & 1085 & Terpinolene & 0.08 \\
\hline & & & Oxygenated monoterpenes & 59.95 \\
\hline 12 & 1031 & 1031 & 1,8-Cineole & 1.44 \\
\hline 14 & 1070 & 1067 & cis Sabinene hydrate & 0.11 \\
\hline 15 & 1073 & 1072 & trans Linalool oxide & 0.06 \\
\hline 17 & 1097 & 1096 & Linalool & 5.67 \\
\hline 18 & 1146 & 1141 & Camphor & 1.05 \\
\hline 19 & 1153 & 1149 & Menthone & 1.08 \\
\hline 20 & 1169 & 1163 & Borneol & 1.79 \\
\hline 21 & 1172 & 1169 & Menthol & 0.48 \\
\hline 22 & 1177 & 1174 & Terpinen-4-ol & 1.97 \\
\hline 23 & 1183 & 1186 & $<$ iso $>$-Menthol & 0.10 \\
\hline 24 & 1189 & 1190 & $\alpha$-Terpineol & 0.11 \\
\hline 25 & 1235 & 1227 & Thymol methyl ether & 0.37 \\
\hline 26 & 1245 & 1237 & Carvacrol methyl ether & 0.51 \\
\hline 27 & 1238 & 1245 & Neral & 0.05 \\
\hline 28 & 1242 & 1249 & Carvone & 0.31 \\
\hline 29 & 1291 & 1281 & p-Cymen-7-ol & 0.05 \\
\hline 30 & 1290 & 1295 & Thymol & 42.10 \\
\hline \multirow[t]{2}{*}{31} & 1299 & 1300 & Carvacrol & 2.70 \\
\hline & & & Sesquiterpenes & 7.93 \\
\hline 32 & 1351 & 1344 & $\alpha$-Cubebene & 0.05 \\
\hline 34 & 1377 & 1369 & $\alpha$-Copaene & 0.15 \\
\hline
\end{tabular}


Table 1. Cont.

\begin{tabular}{ccccc}
\hline$\#^{\mathbf{a}}$ & $\mathbf{R I ~ L i t}^{\mathbf{b}}$ & $\mathbf{R I ~ E x p}^{\mathbf{c}}$ & Class/Compound $^{\mathbf{d}}$ & $\mathbf{\%}^{\mathbf{e}}$ \\
\hline 35 & 1419 & 1411 & $\beta$-Caryophyllene & 6.40 \\
36 & 1466 & 1450 & $<9$-epi-(E)>-Caryophyllene & 0.05 \\
37 & 1485 & 1481 & Germacrene D & 0.08 \\
38 & 1514 & 1500 & $\gamma$-Cadinene & 0.06 \\
39 & 1523 & 1506 & -Cadinene & 0.23 \\
40 & 1583 & 1568 & Caryophyllene oxide & 0.80 \\
41 & 1670 & 1652 & $<$ 14-Hydroxy-9-epi-(E)>-Caryophyllene & 0.11 \\
& & & Others & $\mathbf{1 . 3 2}$ \\
1 & 855 & 858 & 3-Hexen-1-ol & 0.23 \\
6 & 979 & 978 & 1-Octan-3-ol & 0.87 \\
33 & 1359 & 1350 & Eugenol & 0.22 \\
\hline
\end{tabular}

a The numbering refers to elution order; ${ }^{\mathrm{b}}$ Literature retention index (RI); ${ }^{\mathrm{c}}$ Retention index (RI) relative to a standard mixture of $n$-alkanes on $\mathrm{SPB}^{\mathrm{TM}}-5$ column; ${ }^{\mathrm{d}}$ Identified compounds ( $<0.05 \%$ have not been reported); ${ }^{\mathrm{e}}$ Relative peak area percent represent averages of 3 determinations.

Our findings are endorsed by Tardugno et al. [62], who reported that the main constituents of TEO were thymol (35.84-41.15\%), $p$-cymene (17.50-21.73\%), $\gamma$-terpinene (15.06-18.42\%), linalool $(2.55-5.37 \%)$, and carvacrol (1.45-1.70\%). Csikós et al. [63] reported that thymol (46.3\%) and $p$-cymene (22.1\%) were identified as the main components of TEO. Rinaldi et al. [64] showed the presence of thymol as the most abundant (44.4\%) followed by O-cymene (18.2\%) and linalool (7.5\%) in the chemical composition of TEO. Based on these results, our essential oil shows a chemical composition proportionate to those mentioned by other authors who assume its memory-enhancing and antioxidant function.

\subsection{Impact on Anxiety-Like Behavior in NTT and on Spatial Memory in Y-Maze and NOR Tests}

The NTT assesses the anxiety reaction evoked by novelty. Representative locomotion tracking patterns (Figure 2A) shows the variations in swimming traces within the NTT test between the top and the bottom areas. Sco-treated groups displayed a bottom zone preference which indicated high levels of anxiety. In the NTT test, one-way ANOVA revealed significant effect of the treatment on the time spent in the top/bottom zone of the tank $(\mathrm{F}(4.90)=32.65, p<0.0001)$ (Figure $2 \mathrm{~B})$, on the total distance traveled $(\mathrm{F}(4.45)=4.87, p<0.001)$ (Figure $2 \mathrm{C})$, and on the average velocity $(\mathrm{F}(4.45)=10.99$, $p<0.0001$ ) (Figure 2D). Sco treatment significantly increased the time spent in the bottom zone of the tank $(p<0.0001)$ (Figure 2B) compared with the control group. By decreasing the total distance traveled in the tank $(p<0.01)$ (Figure 2C) and the average velocity $(p<0.01)$ (Figure 2D), Sco treatment induced a hypolocomotor effect compared with the control group. The anxiolytic-like effect of the TEO treatment was noticed by decreasing the time spent in the bottom zone of the tank $(p<0.0001)$ (Figure 2B) as compared with the Sco-alone treated animals. Moreover, treatment with TEO prevents the hypolocomotor effect of Sco, in a dose-dependent manner, as evidenced through increasing the total distance traveled $(p<0.001)$ (Figure 2C) and the average velocity $(p<0.01$ for the $25 \mu \mathrm{L} / \mathrm{L}$ and $p<0.0001$ for the $150 \mu \mathrm{L} / \mathrm{L}$ and $300 \mu \mathrm{L} / \mathrm{L}$ ) (Figure 2D) as compared with Sco-alone treated fish.

The typical locomotion tracking pattern (Figure 3A) illustrates the differences in swimming traces among the Y-maze arms. Sco-exposed zebrafish explored the novel arm less, suggesting deficits in the response to novelty. In the Y-maze test, one-way ANOVA revealed significant effect of the treatment on the time spent in each arm $(\mathrm{F}(8.90)=19.60, p<0.0001)$ (Figure 3B), on the total distance traveled $(\mathrm{F}(4.45)=12.47, p<0.0001)$ (Figure $3 \mathrm{C})$, the turn angle $(\mathrm{F}(4.45)=3.53, p<0.01)$ (Figure 3D) and the preference percentages $(\mathrm{F}(4.45)=25.36, p<0.0001)$ (Figure $3 \mathrm{E})$. Sco administration decreased the time spent in the novel arm $(p<0.0001)$ (Figure 3B) as compared with the control group, suggesting memory impairment. Besides, Sco treatment-induced hypolocomotion as evidenced by a decrease of the total distance traveled $(p<0.0001)$ (Figure 3C) and the turn angle $(p<0.001)$ (Figure 3D), as compared with the control group. TEO significantly improved memory deficits as evidenced by an increase of the time spent in the novel arm, in a dose-dependent manner $(p<0.001$ for $25 \mu \mathrm{L} / \mathrm{L}$ and $p<0.0001$ for $150 \mu \mathrm{L} / \mathrm{L}$ and $300 \mu \mathrm{L} / \mathrm{L}$ ) (Figure 3B), as compared to Sco-alone treated fish. Moreover, 
TEO prevented Sco-induced hypolocomotion by significantly increased the total distance traveled in the tank $(p<0.001)$ (Figure 3C). Control group showed preferences for the novel arm in the Y-maze test, while Sco-treated zebrafish displayed less percentage preferences for the novel arm $(p<0.0001)$ (Figure 3E) as compared to control group, suggesting an impaired response to novelty. Besides, administration of TEO $(25,150$, and $300 \mu \mathrm{L} / \mathrm{L})$ in the Sco-treated animals, significantly improved the preference percentages $(p<0.0001$ for 25,150 , and $300 \mu \mathrm{L} / \mathrm{L}$ ) suggesting memory-enhancing profile (Figure 3E). Furtheremore, the preference percentage in control $(\mathrm{t}=21.21, p<0.0001)$, Sco $(\mathrm{t}=9.13$, $p<0.0001)$, TEO $(25 \mu \mathrm{L} / \mathrm{L})+\mathrm{Sco}(\mathrm{t}=21.86, p<0.0001), \mathrm{TEO}(150 \mu \mathrm{L} / \mathrm{L})+\mathrm{Sco}(\mathrm{t}=11.98, p<0.0001)$, and TEO $(300 \mu \mathrm{L} / \mathrm{L})+\mathrm{ScO}(\mathrm{t}=25.59, p<0.0001)$ groups were statistically different from the chance level (50\%) (Figure 3E).

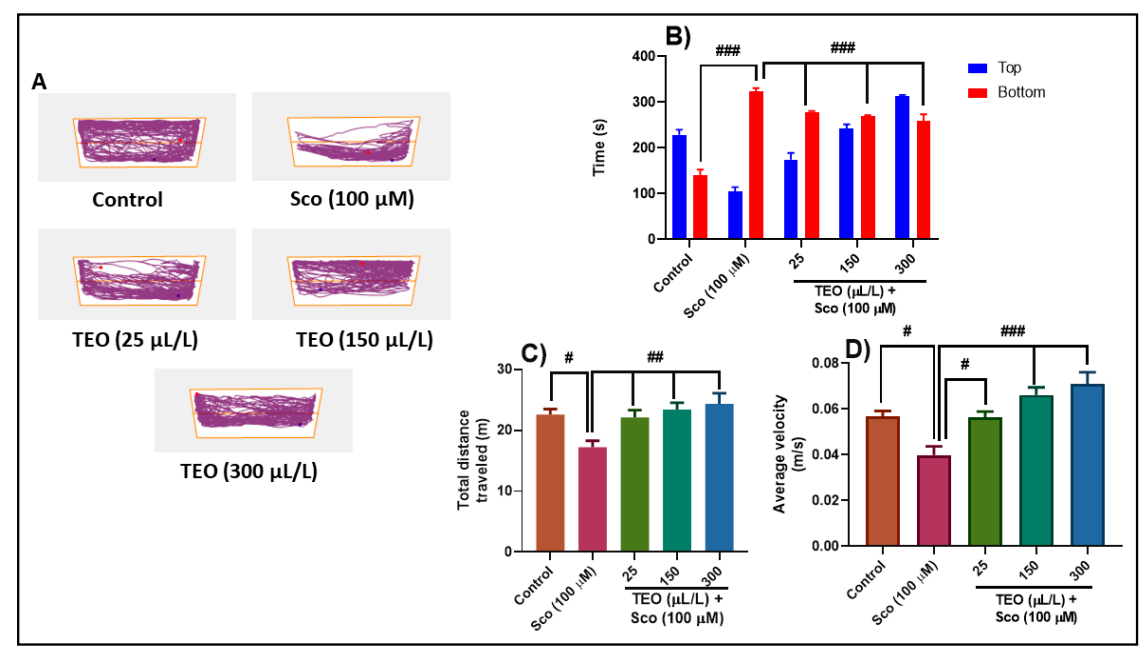

Figure 2. Thymus vulgaris essential oil (TEO: 25, 150, and $300 \mu \mathrm{L} / \mathrm{L}$ ) improved locomotion pattern and reduced anxiety in the novel tank diving (NTT) test. (A) Representative locomotion tracking pattern of the control, scopolamine (Sco: $100 \mu \mathrm{M})$, and TEO (25, 150, and $300 \mu \mathrm{L} / \mathrm{L}$ ) treated groups. (B) Represent the time spent in the top/bottom zone by zebrafish in the tank in different groups. (C) Represent the total distance travelled by zebrafish in the tank in different groups. (D) Represent the average velocity of the zebrafish in different groups. Values are means \pm S.E.M. $(n=10)$. For Tukey's post hoc analyses: (B) Control vs. Sco $(100 \mu \mathrm{M})$ : \#\#\# $p<0.0001$, Sco $(100 \mu \mathrm{M})$ vs. TEO $(25 \mu \mathrm{L} / \mathrm{L})$ : \#\#\# $p<0.0001$, Sco $(100 \mu \mathrm{M})$ vs. TEO $(150 \mu \mathrm{L} / \mathrm{L})$ : \#\#\# $p<0.0001$, and Sco $(100 \mu \mathrm{M})$ vs. TEO $(300 \mu \mathrm{L} / \mathrm{L})$ : \#\#\# $p<0.0001$; (C) Control vs. Sco $(100 \mu \mathrm{M})$ : \# $p<0.01$, Sco $(100 \mu \mathrm{M})$ vs. TEO $(25 \mu \mathrm{L} / \mathrm{L})$ : \#\# $p<0.001$, Sco $(100 \mu \mathrm{M})$ vs. TEO $(150 \mu \mathrm{L} / \mathrm{L})$ : \#\# $p<0.001$, and Sco $(100 \mu \mathrm{M})$ vs. TEO $(300 \mu \mathrm{L} / \mathrm{L})$ : \#\# $p<0.001$; (D) Control vs. Sco $(100 \mu \mathrm{M})$ : \# $p<0.01$, Sco $(100 \mu \mathrm{M})$ vs. TEO $(25 \mu \mathrm{L} / \mathrm{L})$ : \# $p<0.01$, Sco $(100 \mu \mathrm{M})$ vs. TEO $(150 \mu \mathrm{L} / \mathrm{L})$ : \#\#\# $p<0.0001$, and Sco $(100 \mu \mathrm{M})$ vs. TEO $(300 \mu \mathrm{L} / \mathrm{L})$ : \#\#\# $p<0.0001$.

Representative locomotion tracking pattern (Figure 4A) illustrates the differences in the exploration of the familiar object $(\mathrm{F})$ and the novel object $(\mathrm{N})$ within the NOR. In the NOR test, one-way ANOVA revealed significant effect of treatment on the exploratory time $(\mathrm{F}(4.90)=31.38, p<0.0001)$ (Figure $4 \mathrm{~B}$ ) and the preference percentages $(\mathrm{F}(4.45)=3.99, p<0.001)$ (Figure $4 \mathrm{C}$ ). Control group displayed a high preference to explore the $\mathrm{N}(p<0.01)$, whereas Sco-treated group exhibited a high preference $(p<0.01)$ to explore F rather than to explore N, indicating memory impairment (Figure 4B) The Sco-treated zebrafish subjected to either $150 \mu \mathrm{L} / \mathrm{L}$ and $300 \mu \mathrm{L} / \mathrm{L}$ of TEO showed a significantly higher preference for the $\mathrm{N}$ instead of $\mathrm{F}$, suggesting memory improvement profile (Figure $4 \mathrm{~B}$ ). Animals treated with Sco showed fewer percentages of preference $(p<0.001)$ (Figure $4 \mathrm{C})$, as compared with the control group, whereas administration of TEO in the Sco-treated fish improved the percent of preferences for the $\mathrm{N}(p<0.01$ for the 25,150 , and $300 \mu \mathrm{L} / \mathrm{L})$, suggesting a memory-enhancing profile. Furheremore, the preference percentage in control $(t=29.15, p<0.0001)$, Sco $(t=23.22, p<0.0001)$, TEO $(25 \mu \mathrm{L} / \mathrm{L})$ 
$+\mathrm{Sco}(\mathrm{t}=18.42, p<0.0001), \mathrm{TEO}(150 \mu \mathrm{L} / \mathrm{L})+\mathrm{Sco}(\mathrm{t}=19.64, p<0.0001)$, and TEO $(300 \mu \mathrm{L} / \mathrm{L})+\mathrm{Sco}$ $(t=27.90, p<0.0001)$ groups were statistically different from the chance level $(50 \%)$ (Figure $4 C)$.

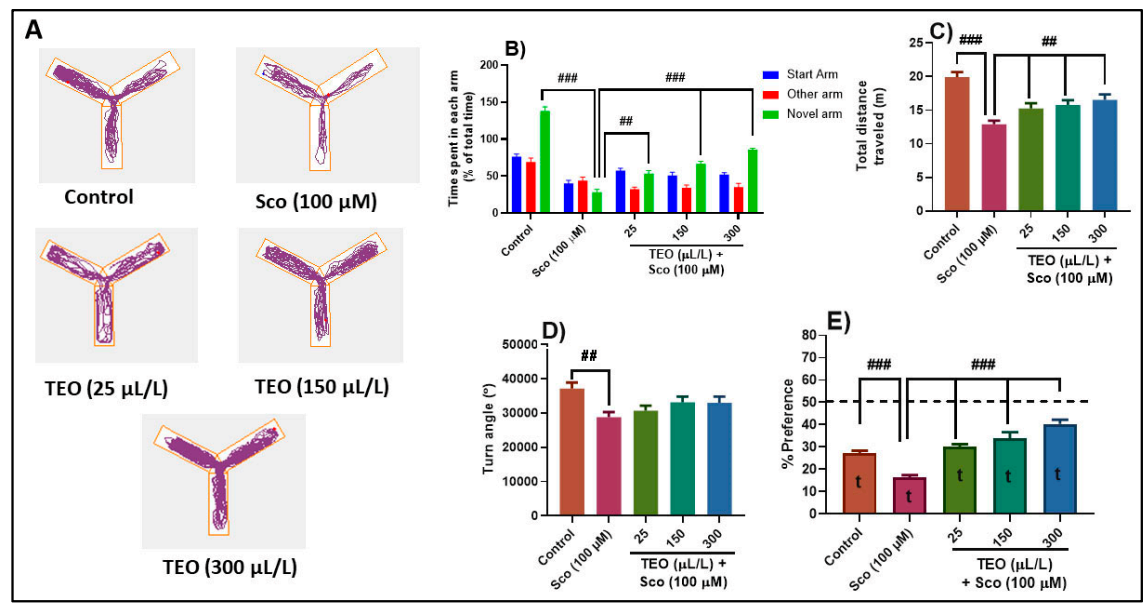

Figure 3. Thymus vulgaris essential oil (TEO: 25, 150, and $300 \mu \mathrm{L} / \mathrm{L}$ ) improved locomotion pattern and memory in the Y-maze test. (A) Representative locomotion tracking pattern of the control, scopolamine (Sco: $100 \mu \mathrm{M})$, and TEO $(25,150$, and $300 \mu \mathrm{L} / \mathrm{L})$ treated groups. (B) Represent time spent in each arm (start, novel and novel arm) in different groups. (C) Represent the total distance traveled by zebrafish in the tank in different groups. (D) Represent the turn angle of zebrafish in the tank in different groups. Values are means \pm S.E.M. $(n=10)$. For Tukey's post hoc analyses: $(\mathbf{B})$ Control vs. Sco $(100 \mu \mathrm{M})$ : \#\#\# $p<0.0001$, Sco vs. TEO $(25 \mu \mathrm{L} / \mathrm{L})$ : \#\# $p<0.001$, Sco vs. TEO $(150 \mu \mathrm{L} / \mathrm{L})$ : \#\#\# $p<0.0001$ and Sco vs. TEO (300 $\mu \mathrm{L} / \mathrm{L})$ : \#\#\# $p<0.0001$; (C) Control vs. Sco $(100 \mu \mathrm{M})$ : \#\#\# $p<0.0001$, Sco vs. TEO $(25 \mu \mathrm{L} / \mathrm{L})$ : \#\# $p<0.001$, Sco vs. TEO $(150 \mu \mathrm{L} / \mathrm{L})$ : \#\# $p<0.001$ and Sco vs. TEO $(300 \mu \mathrm{L} / \mathrm{L})$ : \#\# $p<0.001$; (D) Control vs. Sco $(100 \mu \mathrm{M})$ : \#\# $p<0.001$; (E) Control vs. Sco $(100 \mu \mathrm{M})$ : \#\#\# $p<0.0001$, Sco vs. TEO $(25 \mu \mathrm{L} / \mathrm{L})$ : \#\#\# $p<0.0001$, Sco vs. TEO $(150 \mu \mathrm{L} / \mathrm{L})$ : \#\#\# $p<0.0001$ and Sco vs. TEO $(300 \mu \mathrm{L} / \mathrm{L})$ : \#\#\# $p<0.0001$.

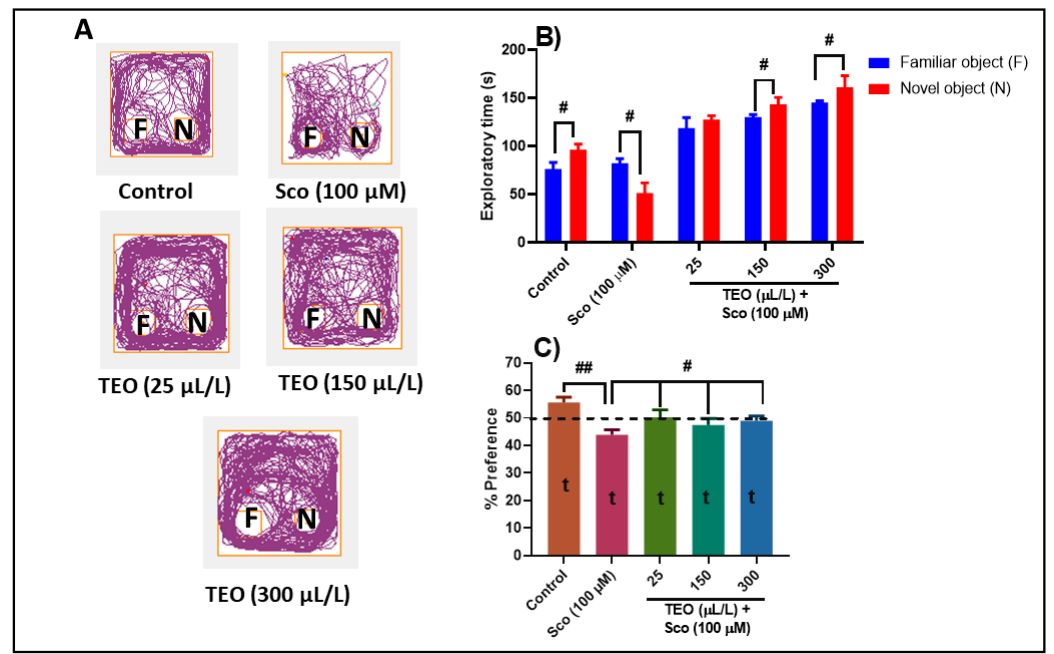

Figure 4. Thymus vulgaris essential oil (TEO: 25, 150, and $300 \mu \mathrm{L} / \mathrm{L}$ ) improved memory in the novel object recognition (NOR) test. (A) Representative locomotion tracking pattern of the control, scopolamine (Sco: $100 \mu \mathrm{M})$, and TEO (25, 150, and $300 \mu \mathrm{L} / \mathrm{L}$ ) treated groups; (B) Represent the exploratory time in different groups; $(\mathbf{C})$ Represent the percentages of preference in different groups. Values are means \pm S.E.M. $(n=10)$. For Tukey's post hoc analyses: (B) \# $p<0.01$; (C) Control vs. Sco $(100 \mu \mathrm{M})$ : \#\# $p<0.001$, Sco vs. TEO $(25 \mu \mathrm{L} / \mathrm{L})$ : \# $p<0.01$, Sco vs. TEO $(150 \mu \mathrm{L} / \mathrm{L})$ : \# $p<0.01$, and Sco vs. TEO $(300 \mu \mathrm{L} / \mathrm{L})$ : $\#<<0.01$.

Additionally, in the control groups exposed to 25, 150, and $300 \mu \mathrm{L} / \mathrm{L}$ doses of TEO, a significant effect on the time spent in top/bottom zone and total distance traveled by zebrafish in the NTT test, 
along with a significant increase of the time spent in the novel arm of the Y-maze test and the exploratory time of the novel object in the NOR test were noticed (Figure S1).

Our results are in line with those recently published by other authors who reported an improvement of cognitive function following the administration of Thymus vulgaris. Akan et al. [65] demonstrated the positive effects of Thymus vulgaris L. and Thymbra spicata L. against diabetes mellitus-induced neuropathy and cognitive impairment as assessed by Morris water maze in rats. The authors attributed the observed effects to the presence in high amounts in the essential oil composition of some components such as thymol, carvacrol, 8 -terpinene, $p$-cymene, and $\alpha$-pinene. Rabiei et al. [37] suggested that the anti-amnesic effect of the Thymus vulgaris extract on Sco-induced memory deficits in rats by using Morris water maze and passive avoidance tests may be related to its antioxidants activity or the mediation of the cholinergic system activity. Again, the authors attributed these effects to carvacrol and thymol as evidenced in the chemical composition. Based on these results, TEO could be considered as an alternative tool for improving cognitive deficits in AD-dementia conditions.

\subsection{Effects on AChE Activity}

The levels of biochemical markers linked to cholinergic function and oxidative stress were examined to elucidate the underlying mechanism of TEO's memory enhancement behavior in Sco-treated fish. Dysfunction and loss of cholinergic neurons in the basal forebrain have been reported to be among the earliest pathological events that occur in $\mathrm{AD}$ pathogenesis and are followed by a decline in the frequency of the choline acetyltransferase (ChAT) and AChE and acetylcholine (ACh) levels in the brains of people with $\mathrm{AD}$ [66]. The change in AChE activity is related to AD progression [67]. The AChE specific activity was significantly increased in the Sco-treated zebrafish compared with the control group $(p<0.0001)$ (Figure 5A). However, the TEO treatment significantly decreased $(p<0.0001)$ (Figure 5A) the AChE specific activity on all doses, and this parallel with the improvement of memory parameters, as evidenced in the behavioral approaches (NTT, Y-maze, and NOR tests). Dandlen et al. [68] demonstrated the AChE inhibition activity of portuguese Thymus species essential oils. Among the Thymus essential oils examined, practically all carvacrol, borneol, or 1,8-cineole rich oils have an inhibitory effect on $\mathrm{AChE}$, indicating that these compounds are important for their bioactivity. Aazza et al. [69], demonstrated that TEO exhibited anti-AChE activity mainly due to the presence of the phenolic monoterpenes thymol and carvacrol. Owokotomo et al. [70] reported AChE inhibition activity of the essential oil from Thymus vulgaris. Kindl et al. [71] highlighted the anticholinesterase potential of six Thymus species. Our data indicate that TEO possesses cholinesterase inhibitory potential, related to the improvement of cognitive dysfunction in Sco-induced amnesic zebrafish.

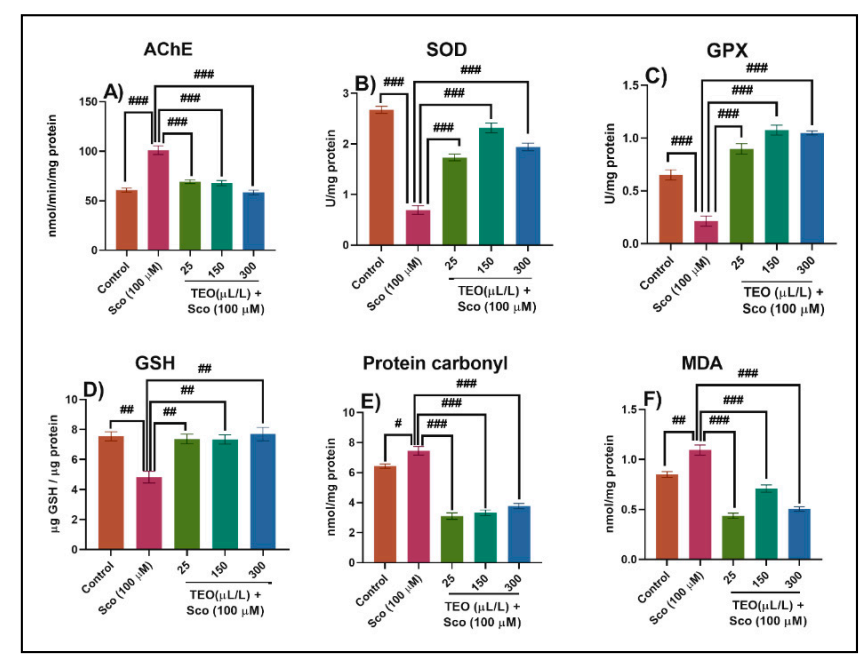

Figure 5. Thymus vulgaris essential oil (TEO: 25,150 , and $300 \mu \mathrm{L} / \mathrm{L}$ ) exhibited an anti- acetylcholinesterase (AChE) effect and improved brain antioxidant status. The enzyme's specific activities: (A) AChE; 
(B) superoxide dismutase (SOD); (C) glutathione peroxidase (GPX); ((D) reduced glutathione (GSH);

(E) protein carbonyl and (F) malondialdehyde (MDA) level. Values are means \pm S.E.M. $(n=10)$.

For Tukey's post hoc analyses: (A) Control vs. Sco $(100 \mu \mathrm{M})$ : \#\#\# $p<0.0001$, Sco vs. TEO $(25 \mu \mathrm{L} / \mathrm{L})$ : \#\#\# $p<0.0001$, Sco vs. TEO (150 $\mu \mathrm{L} / \mathrm{L})$ : \#\#\# $p<0.0001$ and Sco vs. TEO $(300 \mu \mathrm{L} / \mathrm{L})$ : \#\#\# $p<0.0001$; B $)$ Control vs. Sco $(100 \mu \mathrm{M})$ : \#\#\# $p<0.0001$, Sco vs. TEO $(25 \mu \mathrm{L} / \mathrm{L})$ : \#\#\# $p<0.0001$, Sco vs. TEO $(150 \mu \mathrm{L} / \mathrm{L})$ : \#\#\# $p<0.0001$ and Sco vs. TEO $(300 \mu \mathrm{L} / \mathrm{L})$ : \#\#\# $p<0.0001 ;(\mathbf{C})$ Control vs. Sco $(100 \mu \mathrm{M})$ : \#\#\# $p<0.0001$, Sco vs. TEO $(25 \mu \mathrm{L} / \mathrm{L})$ : \#\#\# $p<0.0001$, Sco vs. TEO $(150 \mu \mathrm{L} / \mathrm{L})$ : \#\# $p<0.0001$ and Sco vs. TEO $(300 \mu \mathrm{L} / \mathrm{L})$ : \#\#\# $p<0.0001$; (D) Control vs. Sco $(100 \mu \mathrm{M})$ : \#\# $p<0.001$, Sco vs. TEO $(25 \mu \mathrm{L} / \mathrm{L})$ : \#\# $p<0.001$, Sco vs. TEO $(150 \mu \mathrm{L} / \mathrm{L})$ : \#\# $p<0.001$ and Sco vs. TEO $(300 \mu \mathrm{L} / \mathrm{L})$ : \#\# $p<0.001$; (E) Control vs. Sco $(100 \mu \mathrm{M})$ : $\# p<0.01$, Sco vs. TEO $(25 \mu \mathrm{L} / \mathrm{L})$ : \#\#\# $p<0.0001$, Sco vs. TEO $(150 \mu \mathrm{L} / \mathrm{L})$ : \#\#\# $p<0.0001$ and Sco vs. TEO (300 $\mu \mathrm{L} / \mathrm{L})$ : \#\#\# $p<0.0001$; and (F) Control vs. Sco $(100 \mu \mathrm{M})$ : \#\# $p<0.001$, Sco vs. TEO $(25 \mu \mathrm{L} / \mathrm{L})$ : \#\#\# $p<0.0001$, Sco vs. TEO $(150 \mu \mathrm{L} / \mathrm{L})$ : \#\#\# $p<0.0001$ and Sco vs. TEO $(300 \mu \mathrm{L} / \mathrm{L})$ : \#\#\# $p<0.0001$.

\subsection{Effects on the Brain Oxidative Status}

We investigated SOD and GPX activities and the total content of reduced GSH, protein carbonyl, and MDA levels in the brain tissue to determine whether TEO inhibits oxidative damage induced by Sco. Sco treatment resulted in significant decrease in the specific activities of the antioxidants enzymes-SOD $(p<0.0001)$ (Figure 5B), GPX $(p<0.0001)$ (Figure 5C), the total content of reduced GSH $(p<0.001)$ (Figure 5D), along with increased levels of protein carbonyl $(p<0.01)$ (Figure 5E) and lipid peroxidation (MDA) $(p<0.001)$ (Figure 5F) when compared with the control group. Besides, TEO co-administration significantly ameliorated Sco-induced oxidative stress by enhancing the activity of the antioxidant enzymes and suppressing the levels of protein carbonyl and lipid peroxidation relative to Sco-treated animals.

Oxidative stress is associated with memory impairment in AD [72]. While ROS and free radicals such as superoxide $\left(\mathrm{O}_{2}{ }^{-}\right)$and hydrogen peroxide $\left(\mathrm{H}_{2} \mathrm{O}_{2}\right)$ are produced during normal metabolism, an imbalance between the ROS production and antioxidant leads to oxidative stress in the body [73]. The body has several antioxidant enzymes, such as SOD and GPX to protect it from oxidative stress [73]. SOD acts as the first-line defense against oxidative stress, catalyzes $\mathrm{O}_{2}{ }^{-}$to oxygen $\left(\mathrm{O}_{2}\right)$ and $\mathrm{H}_{2} \mathrm{O}_{2}$, and then $\mathrm{H}_{2} \mathrm{O}_{2}$ is transformed into $\mathrm{H}_{2} \mathrm{O}$ by catalase [74]. Furthermore, GPX reduces both $\mathrm{H}_{2} \mathrm{O}_{2}$ and hydroperoxides by expending glutathione (GSH) [75]. In particular, SOD and GPX play an important role in protecting against oxidative stress in the brain [75,76]. MDA is one of the most significant aldehydes formed after lipid hydroperoxide breakdown. Hence the involvement of free radical damage in pathologies associated with oxidative stress is considered a good biomarker [77]. Furthermore, many studies reported that Sco-induced memory loss is related to increased brain oxidative stress [78,79]. Sco also significantly increases AChE and MDA levels in the cortex and hippocampus [80]. TEO significantly restored the antioxidant status in the zebrafish brain, as evidenced by a significant increase of SOD and GPX activities along with the decrease of the protein carbonyl and MDA levels. Our results are supported by literature concerning the antioxidant effects of the Thymus. By inhibiting lipid peroxidation and activation of the Keap1/Nrf2 pathway in zebrafish, Thymus quinquecostatus Celak. oils have provided protection against oxidative stress in zebrafish, as demonstrated by He et al. [81]. TEO treatment effectively restored the antioxidant defense mechanism by increasing the antioxidant levels of activity in the brain.

Pearson correlation coefficient $(r)$ was used to evaluate the relationship between cognition, antioxidant enzymes, and lipid peroxidation (Figure 6). A high negative correlation between the exploring time of the novel object vs. MDA $(n=10, r=-0.679, p<0.001)$ (Figure 6A) was noticed. The negative value of the $r$ indicates that the improvement of behavioral scores in NOR is well correlated with a low level of MDA, a marker of lipid peroxidation. Additionally, high negative correlations were evidenced by linear regression between GPX vs. MDA ( $n=10, r=-0.816, p<0.0001)$ (Figure 6C) and GSH vs. MDA ( $n=10, r=-0.658, p<0.001$ ) (Figure $6 \mathrm{D})$. However, a positive significant correlation between AChE vs. MDA $(n=10, r=0.676, p<0.001)$ (Figure $6 \mathrm{~B})$ and protein carbonyl vs. MDA $(n=10$, 
$r=0.871, p<0.001$ ) (Figure 6E) was noticed when linear regression was calculated. In this case, the positive values of the $r$ indicate that decreasing of ACh activity and protein carbonyl level is well correlated with decreasing of the MDA level. Kindl et al. [71] also demonstrated a relationship between the antioxidant and anticholinesterase potential of the Thymus species. By using the determination of the $r$, we have shown that improvement of the memory performance in Sco-treated rats is linked to increased antioxidant enzyme activity along with a decreased lipid peroxidation level, supporting the neuroprotective profile of TEO.

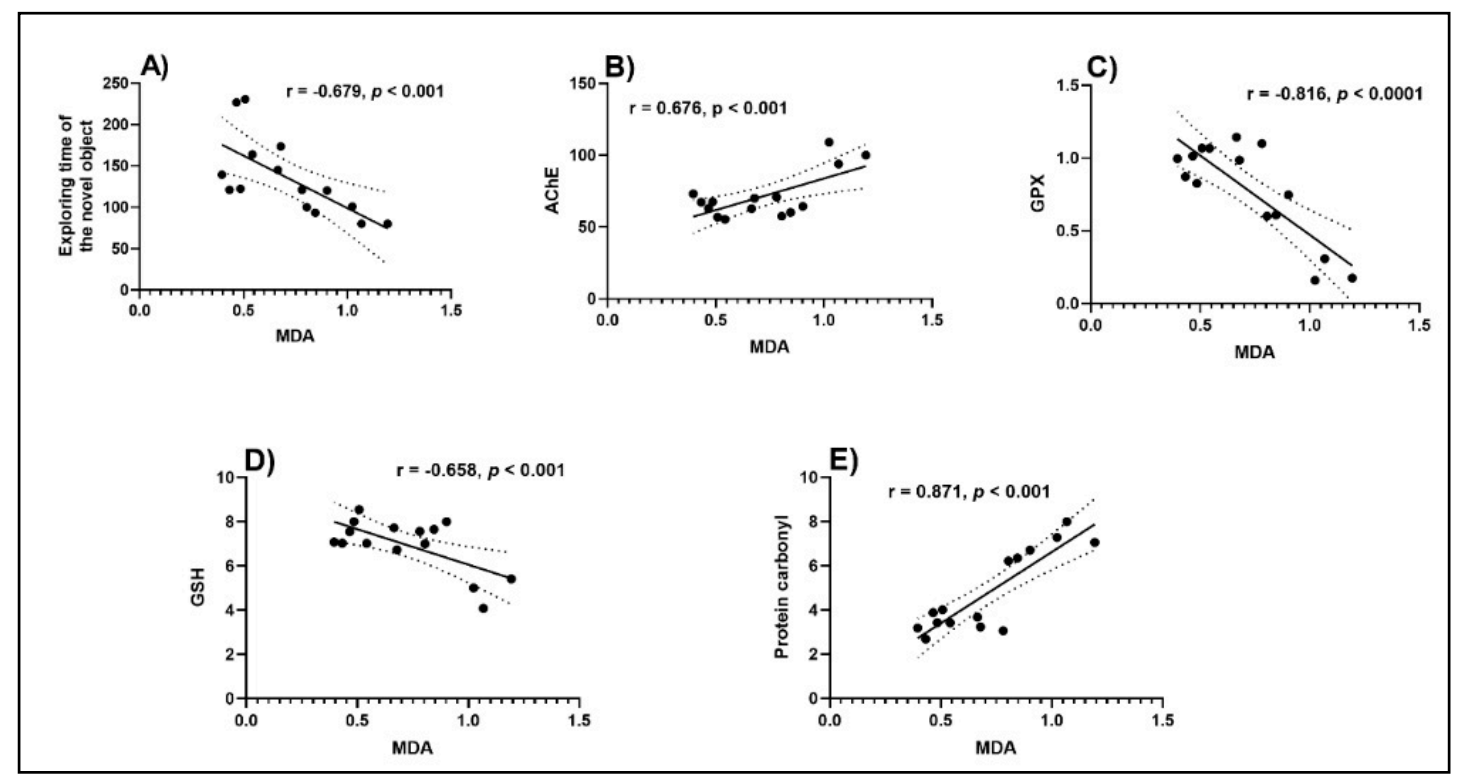

Figure 6. Correlation analyses between behavioral and biochemical parameters (Pearson's correlation, $n=10)$. Data expressed are exploring time of the novel object (s), AChE ( $\mathrm{nmol} / \mathrm{min} / \mathrm{mg}$ protein), GPX (U/mg protein), GSH ( $\mu \mathrm{g} \mathrm{GSH} / \mu \mathrm{g}$ protein), protein carbonyl (nmol/mg protein), and MDA (nmol/mg protein). (A) Exploring time of the novel object vs. MDA $(n=10, r=-0.679, p<0.001)$; (B) AChE vs. MDA $(n=10, r=0.676, p<0.001)$; (C) GPX vs. MDA $(n=10, r=-0.816, p<0.0001)$; (D) GSH vs. MDA $(n=10, r=-0.658, p<0.001)$ and (E) protein carbonyl vs. MDA $(n=10, r=0.871$, $p<0.001)$.

\section{Conclusions}

Considering a very wide range of evidence supporting oxidative stress involvement in neurodegenerative pathologies as well as the fact that $\mathrm{AChE}$ inhibition is up to now the most effective therapeutic approach to dementia, this study aimed to evaluate the neuroprotective potential of the TEO by investigating its cognitive-enhancing, anti-AChE and antioxidant activities in Sco zebrafish model. Our study suggested that the cognitive-protecting activities of TEO on Sco-induced memory impairment might result from its effect on improving the cholinergic nervous system and antioxidative stress. To sum up, TEO might be a promising candidate for the treatment of cognitive dysfunction.

Supplementary Materials: The following are available online at http://www.mdpi.com/2076-3921/9/11/1083/s1, Figure S1: The effects of Thymus vulgaris essential oil (TEO: 25, 150, and $300 \mu \mathrm{L} / \mathrm{L}$ ) on the time spent in top/bottom zone and total distance traveled by zebrafish in the NTT test, the time spent in the novel arm of the Y-maze test and the exploratory time of the novel object in the NOR test in the control groups.

Author Contributions: Conceptualization, L.H. and L.C.; Methodology, L.C., E.T.-C., E.M.N., G.R., and G.D.; Formal Analysis, L.C., E.T.-C., E.M.N., G.R., and G.D.; Investigation, L.C., E.T.-C., E.M.N., G.R., and G.D.; Writing-Original Draft Preparation, L.H., L.C., and E.M.N.; Writing-Review \& Editing, L.H.; Supervision, L.H.; Funding Acquisition, L.H. All authors have read and agreed to the published version of the manuscript.

Funding: This project is funded by the Ministry of Research and Innovation within Program 1-Development of the national RD system, Subprogram 1.2-Institutional Performance-RDI excellence funding projects, Contract no. 34PFE/19.10.2018. Also, this work was co-funded by the European Social Fund, through Operational 
Programme Human Capital 2014-2020, project number POCU/380/6/13/123623, project title: PhD Students and Postdoctoral Researchers Prepared for the Labour Market.

Conflicts of Interest: The authors declare no conflict of interest.

\section{References}

1. Murray, M.E.; Graff-Radford, N.R.; Ross, O.A.; Petersen, R.C.; Duara, R.; Dickson, D.W. Neuropathologically defined subtypes of Alzheimer's disease with distinct clinical characteristics: A retrospective study. Lancet Neurol. 2011, 10, 785-796. [CrossRef]

2. Thomas, D.X.; Bajaj, S.; McRae-McKee, K.; Hadjichrysanthou, C.; Anderson, R.M.; Collinge, J. Association of TDP-43 proteinopathy, cerebral amyloid angiopathy, and Lewy bodies with cognitive impairment in individuals with or without Alzheimer's disease neuropathology. Sci. Rep. 2020, 10, 14579. [CrossRef]

3. Hammond, T.C.; Xing, X.; Wang, C.; Ma, D.; Nho, K.; Crane, P.K.; Elahi, F.; Ziegler, D.A.; Liang, G.; Cheng, Q.; et al. $\beta$-amyloid and tau drive early Alzheimer's disease decline while glucose hypometabolism drives late decline. Commun. Biol. 2020, 3, 1-13. [CrossRef]

4. Lane, C.A.; Hardy, J.; Schott, J.M. Alzheimer's Disease; Blackwell Publishing Ltd.: Oxford, UK, 2018; Volume 25, pp. 59-70.

5. Mufson, E.J.; Counts, S.E.; Perez, S.E.; Ginsberg, S.D. Cholinergic system during the progression of Alzheimer's disease: Therapeutic implications. Expert Rev. Neurother. 2008, 8, 1703-1718. [CrossRef] [PubMed]

6. Odubanjo, V.O.; Ibukun, E.O.; Oboh, G.; Adefegha, S.A. Aqueous extracts of two tropical ethnobotanicals (Tetrapleura tetraptera and Quassia undulata) improved spatial and non-spatial working memories in scopolamine-induced amnesic rats: Influence of neuronal cholinergic and antioxidant systems. Biomed. Pharmacother. 2018, 99, 198-204. [CrossRef] [PubMed]

7. Forester, B.P.; Oxman, T.E. Measures to Assess the Noncognitive Symptoms of Dementia in the Primary Care Setting. Prim. Care Companion J. Clin. Psychiatry 2003, 5, 158-163. [CrossRef] [PubMed]

8. Persson, T.; Popescu, B.O.; Cedazo-Minguez, A. Oxidative stress in alzheimer's disease: Why did antioxidant therapy fail? Oxid. Med. Cell. Longev. 2014. [CrossRef] [PubMed]

9. Hensley, K.; Hall, N.; Subramaniam, R.; Cole, P.; Harris, M.; Aksenov, M.; Aksenova, M.; Gabbita, S.P.; Wu, J.F.; Carney, J.M.; et al. Brain Regional Correspondence Between Alzheimer's Disease Histopathology and Biomarkers of Protein Oxidation. J. Neurochem. 2002, 65, 2146-2156. [CrossRef] [PubMed]

10. Ansari, M.A.; Scheff, S.W. Oxidative stress in the progression of alzheimer disease in the frontal cortex. J. Neuropathol. Exp. Neurol. 2010, 69, 155-167. [CrossRef] [PubMed]

11. Akinyemi, A.J.; Oboh, G.; Oyeleye, S.I.; Ogunsuyi, O. Anti-amnestic Effect of Curcumin in Combination with Donepezil, an Anticholinesterase Drug: Involvement of Cholinergic System. Neurotox. Res. 2017, 31, 560-569. [CrossRef]

12. Hamilton, T.J.; Morrill, A.; Lucas, K.; Gallup, J.; Harris, M.; Healey, M.; Pitman, T.; Schalomon, M.; Digweed, S.; Tresguerres, M. Establishing zebrafish as a model to study the anxiolytic effects of scopolamine. Sci. Rep. 2017, 7, 1-9. [CrossRef]

13. Shabani, S.; Mirshekar, M.A. Diosmin is neuroprotective in a rat model of scopolamine-induced cognitive impairment. Biomed. Pharmacother. 2018, 108, 1376-1383. [CrossRef]

14. Flood, J.F.; Cherkin, A. Scopolamine effects on memory retention in mice: A model of dementia? Behav. Neural Biol. 1986, 45, 169-184. [CrossRef]

15. Brinza, I.; Abd-Alkhalek, A.M.; El-Raey, M.A.; Boiangiu, R.S.; Eldahshan, O.A.; Hritcu, L. Ameliorative effects of rhoifolin in scopolamine-induced amnesic zebrafish (Danio rerio) model. Antioxidants 2020, 9, 580. [CrossRef]

16. Olasehinde, T.A.; Oyeleye, S.I.; Ibeji, C.U.; Oboh, G. Beetroot supplemented diet exhibit anti-amnesic effect via modulation of cholinesterases, purinergic enzymes, monoamine oxidase and attenuation of redox imbalance in the brain of scopolamine treated male rats. Nutr. Neurosci. 2020, 1-15. [CrossRef]

17. Corpuz, H.M.; Fujii, H.; Nakamura, S.; Katayama, S. Fermented rice peptides attenuate scopolamine-induced memory impairment in mice by regulating neurotrophic signaling pathways in the hippocampus. Brain Res. 2019, 1720, 146322. [CrossRef] 
18. Ko, Y.H.; Kwon, S.H.; Lee, S.Y.; Jang, C.G. Liquiritigenin ameliorates memory and cognitive impairment through cholinergic and BDNF pathways in the mouse hippocampus. Arch. Pharm. Res. 2017, 40, 1209-1217. [CrossRef] [PubMed]

19. Diniz, B.S.; Teixeira, A.L. Brain-derived neurotrophic factor and Alzheimer's disease: Physiopathology and beyond. NeuroMolecular Med. 2011, 13, 217-222. [CrossRef]

20. Saura, C.A.; Valero, J. The role of CREB signaling in Alzheimer's disease and other cognitive disorders. Rev. Neurosci. 2011, 22, 153-169. [CrossRef]

21. Kim, D.; Yoon, H.E.; Park, H.S.; Shin, S.J.; Choi, B.S.; Kim, B.S.; Ban, T.H. Development of donepezil-induced hypokalemia following treatment of cognitive impairment. Yeungnam Univ. J. Med. 2020. [CrossRef]

22. Arai, H.; Hashimoto, N.; Sumitomo, K.; Takase, T.; Ishii, M. Disease state changes and safety of long-term donepezil hydrochloride administration in patients with Alzheimer's disease: Japan-Great Outcome of Long-term trial with Donepezil (J-GOLD). Psychogeriatrics 2018, 18, 402-411. [CrossRef] [PubMed]

23. Zhang, X.; Yu, R.; Wang, H.; Zheng, R. Effects of rivastigmine hydrogen tartrate and donepezil hydrochloride on the cognitive function and mental behavior of patients with Alzheimer's disease. Exp. Ther. Med. 2020, 20, 1789-1795. [CrossRef]

24. Matsunaga, S.; Kishi, T.; Iwata, N. Memantine monotherapy for Alzheimer's Disease: A systematic review and meta-analysis. PLoS ONE 2015, 10. [CrossRef] [PubMed]

25. Mir, R.H.; Shah, A.J.; Mohi-ud-din, R.; Potoo, F.H.; Dar, M.A.; Jachak, S.M.; Masoodi, M.H. Natural Anti-inflammatory compounds as Drug candidates in Alzheimer's disease. Curr. Med. Chem. 2020, 27. [CrossRef]

26. Peter, K.V. Handbook of Herbs and Spices; Woodhead Publishing Limited: Cambridge, UK, 2012; ISBN 978-0-85709-039-3.

27. Nikolić, M.; Glamočlija, J.; Ferreira, I.C.F.R.; Calhelha, R.C.; Fernandes, Â.; Marković, T.; Marković, D.; Giweli, A.; Soković, M. Chemical composition, antimicrobial, antioxidant and antitumor activity of Thymus serpyllum L., Thymus algeriensis Boiss. and Reut and Thymus vulgaris L. essential oils. Ind. Crops Prod. 2014, 52, 183-190. [CrossRef]

28. Palmieri, S.; Pellegrini, M.; Ricci, A.; Compagnone, D.; Lo Sterzo, C. Chemical Composition and Antioxidant Activity of Thyme, Hemp and Coriander Extracts: A Comparison Study of Maceration, Soxhlet, UAE and RSLDE Techniques. Foods 2020, 9, 1221. [CrossRef]

29. Agatonovic-Kustrin, S.; Kustrin, E.; Morton, D.W. Essential oils and functional herbs for healthy aging. Neural Regen. Res. 2019, 14, 441-445. [CrossRef]

30. Asadbegi, M.; Yaghmaei, P.; Salehi, I.; Komaki, A.; Ebrahim-Habibi, A. Investigation of thymol effect on learning and memory impairment induced by intrahippocampal injection of amyloid beta peptide in high fat diet- fed rats. Metab. Brain Dis. 2017, 32, 827-839. [CrossRef]

31. Capibaribe, V.C.C.; Vasconcelos Mallmann, A.S.; Lopes, I.S.; Oliveira, I.C.M.; de Oliveira, N.F.; Chaves, R.D.C.; Fernandes, M.L.; de Araujo, M.A.; da Silva, D.M.A.; Valentim, J.T.; et al. Thymol reverses depression-like behaviour and upregulates hippocampal BDNF levels in chronic corticosterone-induced depression model in female mice. J. Pharm. Pharmacol. 2019, 71, 1774-1783. [CrossRef]

32. De Formiga, R.O.; Alves Júnior, E.B.; Vasconcelos, R.C.; Guerra, G.C.B.; de Araújo, A.A.; de Carvalho, T.G.; Garcia, V.B.; de Araújo Junior, R.F.; Gadelha, F.A.A.F.; Vieira, G.C.; et al. P-cymene and rosmarinic acid ameliorate tnbs-induced intestinal inflammation upkeeping zo-1 and muc-2: Role of antioxidant system and immunomodulation. Int. J. Mol. Sci. 2020, 21, 5870. [CrossRef]

33. Azizi, Z.; Salimi, M.; Amanzadeh, A.; Majelssi, N.; Naghdi, N. Carvacrol and thymol attenuate cytotoxicity induced by amyloid $\beta 25-35$ via activating protein kinase $C$ and inhibiting oxidative stress in PC12 cells. Iran. Biomed. J. 2020, 24, 243-250. [PubMed]

34. Andre, C.M.; Hausman, J.-F.; Guerriero, G. Cannabis sativa: The Plant of the Thousand and One Molecules. Front. Plant. Sci. 2016, 7. [CrossRef]

35. Nuutinen, T. Medicinal properties of terpenes found in Cannabis sativa and Humulus lupulus. Eur. J. Med. Chem. 2018, 157, 198-228. [CrossRef]

36. Pellati, F.; Brighenti, V.; Sperlea, J.; Marchetti, L.; Bertelli, D.; Benvenuti, S. New Methods for the Comprehensive Analysis of Bioactive Compounds in Cannabis sativa L. (hemp). Molecules 2018, 23, 2639. [CrossRef] [PubMed] 
37. Rabiei, Z.; Mokhtari, S.; Asgharzade, S.; Gholami, M.; Rahnama, S.; Rafieian-Kopaei, M. Inhibitory effect of Thymus vulgaris extract on memory impairment induced by scopolamine in rat. Asian Pac. J. Trop. Biomed. 2015, 5, 845-851. [CrossRef]

38. Elaissi, A.; Elsharkawy, E.; El Mokni, R.; Debbabi, H.; Brighenti, V.; Nardoni, S.; Pellati, F.; Hammami, S. Chemical composition, antifungal and antiproliferative activities of essential oils from Thymus numidicus $\mathrm{L}$. Nat. Prod. Res. 2020. [CrossRef]

39. Butt, A.S.; Nisar, N.; Mughal, T.A.; Ghani, N.; Altaf, I. Anti-oxidative and anti-proliferative activities of extracted phytochemical compound thymoquinone. J. Pak. Med. Assoc. 2019, 69, 1479-1485. [CrossRef]

40. Napoli, E.M.; Curcuruto, G.; Ruberto, G. Screening of the essential oil composition of wild Sicilian thyme. Biochem. Syst. Ecol. 2010, 38, 816-822. [CrossRef]

41. NIST Standard Reference Database 1A. Available online: https:/www.nist.gov/system/files/documents/srd/ NIST1aVer22Man.pdf (accessed on 10 January 2020).

42. Adams, R.P. Identification of Essential Oil Components by Gas Chromatography/Mass Spectroscopy; Allured Pub. Corporation: Carol Stream, IL, USA, 2007; ISBN 1932633219.

43. Dos Santos, A.C.; Junior, G.B.; Zago, D.C.; Zeppenfeld, C.C.; da Silva, D.T.; Heinzmann, B.M.; Baldisserotto, B.; da Cunha, M.A. Anesthesia and anesthetic action mechanism of essential oils of Aloysia triphylla and Cymbopogon flexuosus in silver catfish (Rhamdia quelen). Vet. Anaesth. Analg. 2017, 44, 106-113. [CrossRef]

44. Capatina, L.; Boiangiu, R.S.; Dumitru, G.; Napoli, E.M.; Ruberto, G.; Hritcu, L.; Todirascu-Ciornea, E. Rosmarinus officinalis Essential Oil Improves Scopolamine-Induced Neurobehavioral Changes via Restoration of Cholinergic Function and Brain Antioxidant Status in Zebrafish (Danio rerio). Antioxidants 2020, 9, 62. [CrossRef]

45. Zanandrea, R.; Abreu, M.S.; Piato, A.; Barcellos, L.J.G.; Giacomini, A.C.V.V. Lithium prevents scopolamine-induced memory impairment in zebrafish. Neurosci. Lett. 2018, 664, 34-37. [CrossRef]

46. Cachat, J.M.; Canavello, P.R.; Elkhayat, S.I.; Bartels, B.K.; Hart, P.C.; Elegante, M.F.; Beeson, E.C.; Laffoon, A.L.; Haymore, W.A.M.; Tien, D.H.; et al. Video-aided analysis of zebrafish locomotion and anxiety-related behavioral responses. Neuromethods 2011, 51, 1-14.

47. Cognato, G.D.P.; Bortolotto, J.W.; Blazina, A.R.; Christoff, R.R.; Lara, D.R.; Vianna, M.R.; Bonan, C.D. Y-Maze memory task in zebrafish (Danio rerio): The role of glutamatergic and cholinergic systems on the acquisition and consolidation periods. Neurobiol. Learn. Mem. 2012, 98, 321-328. [CrossRef] [PubMed]

48. Gaspary, K.V.; Reolon, G.K.; Gusso, D.; Bonan, C.D. Novel object recognition and object location tasks in zebrafish: Influence of habituation and NMDA receptor antagonism. Neurobiol. Learn. Mem. 2018, 155, 249-260. [CrossRef]

49. Batista, F.L.A.; Lima, L.M.G.; Abrante, I.A.; de Araújo, J.I.F.; Batista, F.L.A.; Abrante, I.A.; Magalhães, E.A.; de Lima, D.R.; Da Lima, M.C.L.; do Prado, B.S.; et al. Antinociceptive activity of ethanolic extract of Azadirachta indica A. Juss (Neem, Meliaceae) fruit through opioid, glutamatergic and acid-sensitive ion pathways in adult zebrafish (Danio rerio). Biomed. Pharmacother. 2018, 108, 408-416. [CrossRef]

50. Ellman, G.; Courtney, K.; Andres, V.J.; Feather-Stone, R. A new and rapid colorimetric determination of acetylcholinesterase activity. Biochem. Pharmacol. 1961, 7, 88-95. [CrossRef]

51. Winterbourn, C.; Hawkins, R.; Brian, M.; Carrell, R. The estimation of red cell superoxide dismutase activity. J. Lab. Clin. Med. 1975, 85, 337.

52. Sharma, M.; Gupta, Y.K. Chronic treatment with trans resveratrol prevents intracerebroventricular streptozotocin induced cognitive impairment and oxidative stress in rats. Life Sci. 2002, 7, 2489-2498. [CrossRef]

53. Fukuzawa, K.; Tokumura, A. Glutathione peroxidase activity in tissues of vitamin E-deficient mice. J. Nutr. Sci. Vitaminol. 1976, 22, 405-407. [CrossRef]

54. Oliver, C.N.; Ahn, B.W.; Moerman, E.J.; Goldstein, S.; Stadtman, E.R. Age-related changes in oxidized proteins. J. Biol. Chem. 1987, 262, 5488-5491.

55. Luo, S.; Wehr, N.B. Protein carbonylation: Avoiding pitfalls in the 2,4-dinitrophenylhydrazine assay. Redox Rep. 2009, 14, 159-166. [CrossRef]

56. Ohkawa, H.; Ohishi, N.; Yagi, K. Assay for lipid peroxides in animal tissues by thiobarbituric acid reaction. Anal. Biochem. 1979, 95, 351-358. [CrossRef]

57. Bradford, M.M. A rapid and sensitive for the quantitation of microgram quantitites of protein utilizing the principle of protein-dye binding. Anal. Biochem. 1976, 72, 248-254. [CrossRef] 
58. Napoli, E.M.; Ruberto, G. Sicilian aromatic plants: From traditional heritage to a new agro-industrial exploitation. In Spices: Types, Uses and Health Benefits; Kralis, J.F., Ed.; NovaPublishers: Hauppauge, NY, USA, 2012; ISBN 9781614708209.

59. Saija, A.; Speciale, A.; Trombetta, D.; Leto, C.; Tuttolomondo, T.; La Bella, S.; Licata, M.; Virga, G.; Bonsangue, G.; Gennaro, M.C.; et al. Phytochemical, Ecological and Antioxidant Evaluation of Wild Sicilian Thyme: Thymbra capitata (L.) Cav. Chem. Biodivers. 2016, 13, 1641-1655. [CrossRef] [PubMed]

60. Napoli, E.; Siracusa, L.; Ruberto, G. New Tricks for Old Guys: Recent Developments in the Chemistry, Biochemistry, Applications and Exploitation of Selected Species from the Lamiaceae Family. Chem. Biodivers. 2020, 17, e1900677. [CrossRef]

61. György, Z.; Incze, N.; Pluhár, Z. Differentiating Thymus vulgaris chemotypes with ISSR molecular markers. Biochem. Syst. Ecol. 2020, 92, 104118. [CrossRef]

62. Tardugno, R.; Serio, A.; Purgatorio, C.; Savini, V.; Paparella, A.; Benvenuti, S. Thymus vulgaris L. essential oils from Emilia Romagna Apennines (Italy): Phytochemical composition and antimicrobial activity on food-borne pathogens. Nat. Prod. Res. 2020, 1-6. [CrossRef]

63. Csikós, E.; Csekő, K.; Ashraf, A.R.; Kemény, Á.; Kereskai, L.; Kocsis, B.; Böszörményi, A.; Helyes, Z.; Horváth, G. Effects of Thymus vulgaris L., Cinnamomum verum J.Presl and Cymbopogon nardus (L.) Rendle Essential Oils in the Endotoxin-induced Acute Airway Inflammation Mouse Model. Molecules 2020, 25, 3553. [CrossRef]

64. Rinaldi, F.; Oliva, A.; Sabatino, M.; Imbriano, A.; Hanieh, P.N.; Garzoli, S.; Mastroianni, C.M.; De Angelis, M.; Miele, M.C.; Arnaut, M.; et al. Antimicrobial Essential Oil Formulation: Chitosan Coated Nanoemulsions for Nose to Brain Delivery. Pharmaceutics 2020, 12, 678. [CrossRef] [PubMed]

65. Akan, Z.; Dikilidal, M.; Ozdemir, H.; Oto, G.; Yilmaz, A. Effects of Thymus Vulgaris, L. and Thymbra Spicata, L. on diabetes mellitus associated cognitive impairment and neuropathy: Thymus Vulgaris and Cognitive Function Improvements. Med. Sci. Discov. 2014, 1, 16. [CrossRef]

66. Nyakas, C.; Granic, I.; Halmy, L.G.; Banerjee, P.; Luiten, P.G.M. The basal forebrain cholinergic system in aging and dementia. Rescuing cholinergic neurons from neurotoxic amyloid- $\beta 42$ with memantine. Behav. Brain Res. 2011, 221, 594-603. [CrossRef]

67. Gauthier, S. Advances in the pharmacotherapy of Alzheimer's disease. CMAJ 2002, 166, 616-623.

68. Dandlen, S.A.; Miguel, M.G.; Duarte, J.; Faleiro, M.L.; Sousa, M.J.; Lima, A.S.; Figueiredo, A.C.; Barroso, J.G.; Pedro, L.G. Acetylcholinesterase Inhibition Activity of Portuguese Thymus Species Essential Oils. J. Essent. Oil Bear. Plants 2011, 14, 140-150. [CrossRef]

69. Aazza, S.; Lyoussi, B.; Miguel, M.G. Antioxidant and Antiacetylcholinesterase Activities of Some Commercial Essential Oils and Their Major Compounds. Molecules 2011, 16, 7672-7690. [CrossRef]

70. Owokotomo, I.A.; Ekundayo, O.; Abayomi, T.G.; Chukwuka, A.V. In-vitro anti-cholinesterase activity of essential oil from four tropical medicinal plants. Toxicol. Rep. 2015, 2, 850-857. [CrossRef]

71. Kindl, M.; Blažeković, B.; Bucar, F.; Vladimir-Knežević, S. Antioxidant and anticholinesterase potential of six Thymus species. Evidence-based Complement. Altern. Med. 2015, 2015. [CrossRef]

72. Valko, M.; Leibfritz, D.; Moncol, J.; Cronin, M.T.D.; Mazur, M.; Telser, J. Free radicals and antioxidants in normal physiological functions and human disease. Int. J. Biochem. Cell Biol. 2007, 39, 44-84. [CrossRef]

73. Marcus, D.L.; Thomas, C.; Rodriguez, C.; Simberkoff, K.; Tsai, J.S.; Strafaci, J.A.; Freedman, M.L. Increased Peroxidation and Reduced Antioxidant Enzyme Activity in Alzheimer's Disease. Exp. Neurol. 1998, 150, 40-44. [CrossRef]

74. Fukai, T.; Ushio-Fukai, M. Superoxide dismutases: Role in redox signaling, vascular function, and diseases. Antioxid. Redox Signal. 2011, 15, 1583-1606. [CrossRef]

75. Kim, J.H.; He, M.T.; Kim, M.J.; Yang, C.Y.; Shin, Y.S.; Yokozawa, T.; Park, C.H.; Cho, E.J. Safflower (Carthamus tinctorius L.) seed attenuates memory impairment induced by scopolamine in mice via regulation of cholinergic dysfunction and oxidative stress. Food Funct. 2019, 10, 3650-3659. [CrossRef]

76. Grundman, M.; Delaney, P. Antioxidant strategies for Alzheimer's disease. Proc. Nutr. Soc. 2002, 61, 191-202. [CrossRef] [PubMed]

77. Zelzer, S.; Oberreither, R.; Bernecker, C.; Stelzer, I.; Truschnig-Wilders, M.; Fauler, G. Measurement of total and free malondialdehyde by gas-chromatography mass spectrometry-comparison with high-performance liquid chromatography methology. Free Radic. Res. 2013, 47, 651-656. [CrossRef] 
78. Hernández-Rodríguez, M.; Arciniega-Martínez, I.M.; García-Marín, I.D.; Correa-Basurto, J.; Rosales-Hernández, M.C. Chronic Administration of Scopolamine Increased GSK3 $\beta$ P9, Beta Secretase, Amyloid Beta, and Oxidative Stress in the Hippocampus of Wistar Rats. Mol. Neurobiol. 2020, 57, 3979-3988. [CrossRef]

79. Lv, J.; Lu, C.; Jiang, N.; Wang, H.; Huang, H.; Chen, Y.; Li, Y.; Liu, X. Protective effect of ginsenoside Rh2 on scopolamine-induced memory deficits through regulation of cholinergic transmission, oxidative stress and the ERK-CREB-BDNF signaling pathway. Phyther. Res. 2020. [CrossRef]

80. Rahnama, S.; Rabiei, Z.; Alibabaei, Z.; Mokhtari, S.; Rafieian-kopaei, M.; Deris, F. Anti-amnesic activity of Citrus aurantium flowers extract against scopolamine-induced memory impairments in rats. Neurol. Sci. 2015, 36, 553-560. [CrossRef]

81. He, T.; Li, X.; Wang, X.; Xu, X.; Yan, X.; Li, X.; Sun, S.; Dong, Y.; Ren, X.; Liu, X.; et al. Chemical composition and anti-oxidant potential on essential oils of Thymus quinquecostatus Celak. from Loess Plateau in China, regulating Nrf2/Keap1 signaling pathway in zebrafish. Sci. Rep. 2020, 10, 1-18. [CrossRef] [PubMed]

Publisher's Note: MDPI stays neutral with regard to jurisdictional claims in published maps and institutional affiliations.

(C) 2020 by the authors. Licensee MDPI, Basel, Switzerland. This article is an open access article distributed under the terms and conditions of the Creative Commons Attribution (CC BY) license (http://creativecommons.org/licenses/by/4.0/). 